\title{
The stimulatory effect of male agouti (Dasyprocta prymnolopha) on the onset of female puberty
}

Diva Anelie de Araújo GUIMARÃES ${ }^{1}$, Rosemar Silva Luz RAMOS², Gary Wayne GARCIA³, Otávio Mitio $\mathrm{OHASHI}^{4}$

\section{ABSTRACT}

The objective of this research was to analyze female agouti puberty. We did not observe the onset of puberty when the females were raised without males. When an adult male was put together with other adults and no cycling females, the onset of estrous cycle was observed after 10 to 60 days. When the young females were raised with a male, the onset of puberty was reached at 9 months. We concluded that the male agouti influences the onset of puberty in females, and that the dominant female, apparently, inhibits or delays the puberty of the other agouti females of the group. We suggest further studies be made concerning the social control of the reproduction of these animal.

KEYWORDS: Agouti; Reproduction; Puberty; Estrous cycle; Captivity

\section{O efeito estimulatório do macho de cutia (Dasyprocta prymnolopha) no inicio da puberdade das fêmeas}

RESUMO

O objetivo desta pesquisa foi analisar a puberdade em fêmeas de cutias. Não foi observado o inicio da puberdade quando as fêmeas foram mantidas sem os machos. Se um macho adulto era mantido com as fêmeas adultas e não ciclantes, o inicio do ciclo estral era observado após um período de 10 a 60 dias. Quando as fêmeas jovens eram mantidas com o macho, a puberdade se estabelecia aos nove meses. Concluindo que o macho de cutia influencia o inicio da puberdade das fêmeas, e as fêmeas dominantes, aparentemente, inibem ou atrasam a puberdade de outras do grupo. Sugerem-se estudos futuros sobre o controle social na reprodução deste animal.

PALAVRAS-Chave: Cutia; Reprodução; Puberdade; Ciclo estral; Cativeiro

\footnotetext{
1 Universidade Federal do Pará. E-mail: diva@ufpa.br

2 Universidade Federal do Pará. E-mail: roseluz@ufpa.br

${ }^{3}$ University of the West Indies. E-mail: garygwg1@gmail.com

${ }^{4}$ Universidade Federal do Pará. E-mail: ohashi@ufpa.br
} 


\section{INTRODUCTION}

Wild animals have been raised in captivity for commercial purposes in Latin America and the Caribbean; one is the agouti (Dasyprocta sp.), a hystricomorpha rodent that is well adapted to this breeding system. The tradicional native Amazonian inhabitants appreciate this bush meat, as a good source of protein (Smith, 1976; Wetterberg et al., 1976; Bodmer, et al., 2004, Bonaudo et al., 2005).

Biological studies are necessary for the management of wild animals in captivity, and knowledge of reproductive parameters is one of the most important features for increasing production. Puberty studies on mammals give information on suitable management practices in breeding programs, selecting individuals for reproduction, and increasing the productivity, efficiency and the genetic improvement of livestock.

Ovarian activity regulates the onset of puberty in female mammals. However, in different species this period is variable and, among other things, it depends on age, weight body, nutrition, genetics and photoperiod (Hafez, 2004). Other specific aspects are also observed, for example, the onset of puberty in the sow is stimulated by a mature boar. The mechanism involved is unclear, but a pheromone has been implicated (Hemsworth, 1999).

Considerable effort has improved the knowledge of the reproduction of captive female agouti (Weir, 1971; Weir, 1974; Guimarães, 1993; Guimarães, 2000). This animal shows an estrous cycle of $30.69 \pm 4.65$ days, a mean gestation of $104.33 \pm 0.57$ days, a litter of two newborns, and parturitions distributed throughout the year (Guimarães, 1993; Guimarães, 2000). Roth-Kolar (1957) reported that the puberty of the female agouti occurred at 6 months of age, and Weir (1971) suggested after 24 .

This study analyses the puberty age of the female agouti (Dasyprocta prymnolopha) and describes the effect of the male agouti at the onset of puberty.

\section{MATERIAL AND METHODS}

Material was collected during an entire year at the breeding grounds of the Animal Reproduction Laboratory of the Federal University of Pará, Brazil.

The annual average temperature was $28^{\circ} \mathrm{C}$ and the natural luminosity was 12 hours a day. All the agoutis (Dasyprocta prymnolopha) were born at the breeding grounds $(1.21 \times 3.13$ $\mathrm{m})$ and were from F3 and F4 generations (Figure 1).

Daily food supply was composed of corn bran (Zea mays), soy (Glycine hispida), pumpkin (Curcibita pepo), cassava (Manihot utilissima) and mineral salt, with periodic administration of a nutritional complement (Potenay Oral NF - Fort Dodge Saúde Animal Ltda., Brazil).

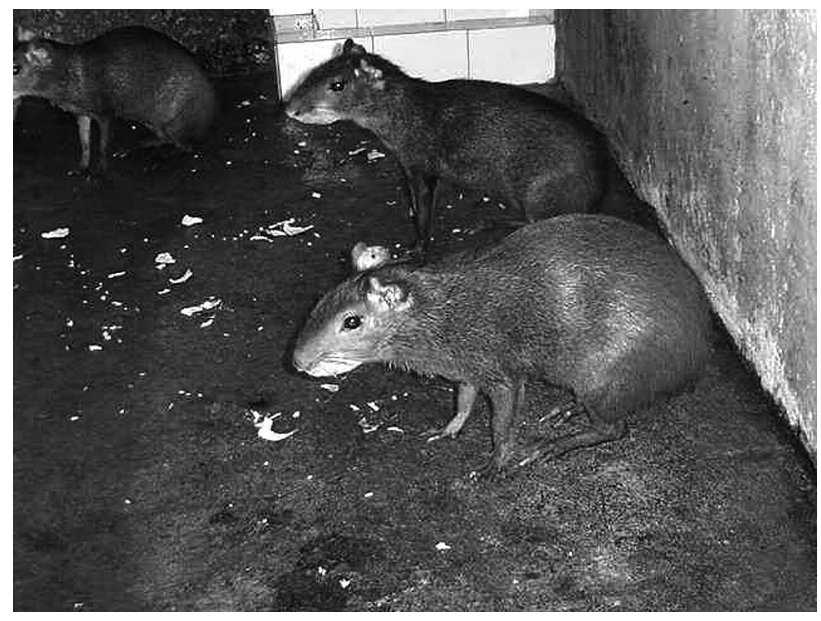

Figure 1- The agouti (Dayprocta prymnolopha) born and raised in captivity at Federal University of Pará, Brazil.

This study verified the influence of the male agouti at the onset of female puberty and was undertaken by the following groups:

Control group: made by two subgroups of three females (4 months) with a sexual mature adult male (18 months) for each subgroup;

First experimental group: made up of two subgroups of three females ( 4 months) isolated from the males. From six months of age, colpocytology was performed twice a week (72 and 96 hour intervals).

If the estrus was not confirmed, a vasectomized male (18 months) was put in each group.

Second experimental group: the females were kept together with the male after weaning. In this experiment 27 animals were mated, aged 28 days, forming six groups of the same age, composed of three females for each male, and a group with two females and a male. We observed the genital region of the female, from the sixth month, three times a week ( 48 and 72 hour intervals). At the occurrence of the first vaginal opening, colpocytology was performed to confirm this phase of the cycle.

The cells of the vaginal epithelium were collected with an $8 \mathrm{~cm}$ swab. This was introduced half way into the vaginal orifice, and with circular movements, the cells were harvested. Then, the material was scattered over the plate. The smear was immediately transferred to $95 \%$ alcohol and colored by the Papanicolau technique.

The cellular characterization of the estrous cycle phases was applied according to Guimaráes et al. (1997), in the following order: in the proestrus, a higher frequency of superficial and intermediate cells were considered; in estrus, a higher number of superficial cells; in metaestrus, the predominance 
of intermediate cells and leukocytes; in the diestrus, the prevalence of parabasal cells and the increase of basal cells. In the female that reach the age of puberty, diagnosing the occurence of copulation was confirmed by the presence of spermatozoas (Figure 2).

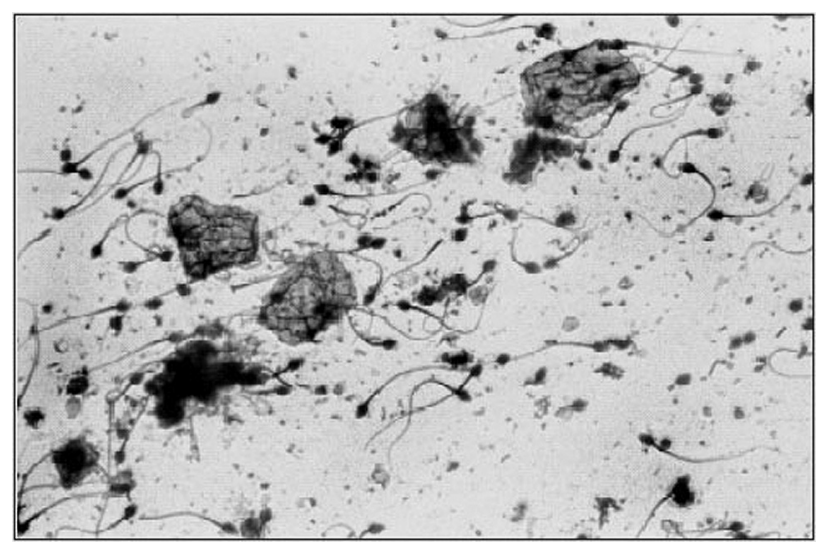

Figure 2 - Colpocitology in agouti (Dasyprocta prymnolopha), showing spermatozoas and superficial cells. $1000 \mathrm{X}$.

\section{RESULTS AND DISCUSSION}

In the control group, we found that the onset of puberty in the six females was at $9.83 \pm 1.72$ months (eight to 11 months). In this period, the female weighed around 1951.66 $\pm 307.27 \mathrm{~g}$.

All six females copulated, four of them in the first estrus, and two after the second and fourth cycles. Gestation was considered normal only in one animal; in four others, there were reproductive problems (fetal death and abortion) and in one the pregnancy was not confirmed. Similarly, RothKolar (1957) observed that some female agouti failed to reproduce during the first gestation. The cause may be related to biological, physiological and anatomical factors associated with maternal age.

In the first experimental group, the estrus was not confirmed until the females were 16 months old. Then, an 18 month old vasectomized male was put in each group. We observed that all females started the ovarian activity at $17.5 \pm$ 1.4 months (16 to 19 months) after 10 to 60 days of contact with the male. During this period, the average weight of the female was $2692 \pm 141.66 \mathrm{~g}$.

In the second experimental group, the onset of puberty in 15 females $(75 \%)$ was reached at $9.33 \pm 0.62$ months ( 8 to 10 months). Two other females reached puberty at 14 to 15 months, and in three it was not detected even after 18 to 19 months. Six copulated, four developed normal gestation and in two pregnancy was not confirmed.
In the mating period, the males were about $10 \pm 0.89$ months old (9 to 11 months). According to Ferreira et al. (2004) the onset of puberty in the agouti male was reached at 8 to 9 months and the sexual maturity was attained at $16-17$ months.

The average duration of the estrous cycle observed in eight females was $30.5 \pm 3.54$ days ( 24 to 37 days) $(\mathrm{n}=22)$, similar to that found by Weir (1971) and Guimaráes (1993).

In each agouti female, a small central opening of the vaginal membrane was observed, approximately, one month before the first oestrus. This central point opened from the center to the periphery, making the vaginal membrane disappear, as observed in some other hystricomorpha rodents. In those animals, the ovarian cyclic activity was not proved; the small central opening appeared at random; and there was never any evidence of a total opening.

Similarly, Stockaar \& Papanicolau (1919) observed in Cavia porcellus, some days before the first oestrus, the rupture of the vaginal membrane, which was kept open during this period.

A significant difference $(\mathrm{p}<0.05)$ between average age, among the mated and isolated females that have reached puberty, indicates that the male is influential in this period. This observation is similar to the one related by Weir (1974) who noted the late puberty and absence of first estrus of Proechimys guaire and Galea musteloides females isolated from males. Probably, the pheromones that are in the urine of the male and also physical signs (visual, auditory, tactile) stimulate female agouti that have reached puberty.

The puberty age at nine months for female agoutis observed in this study is higher than the one related by RothKolar (1957) which was at six months, and lower than the one found by Weir (1971) who suggested after 24 months. However, these authors related only one case. The cause of the delay or the absence of first oestrus in some agouti females may be due to physical signs and to dominant female pheromone. This social control of reproduction was also observed among the Georychus capensis (Bennet \& Jarvis, 1988a), Cryptomys damarensis (Bennet \& Jarvis, 1988b), Heterocephalus glaber (Faulkes et al., 1990) and Hystrix africaeaustralius (Van Aarde \& Van Wyk, 1991).

In conclusion, we suggest that the onset of puberty in female agoutis is influenced by the male and the delay by a dominant female. This is an important factor for appropriate captive breeding system management practices of the agoutis, since the commerce of agouti products is very important in Latin America and the Caribbean. Nevertheless, more studies on pheromone and behaviour of the male and the female are needed. 


\section{ACKNOWLEDGEMENTS}

We thank the Federal University of Pará; their technicians for assistance in collecting materials for this research; and the International Foundation for Science (Ref. B/2659-1) for supporting this project.

\section{LITERATURE CITED}

Bennett N.C. \& Jarvis J.U.M. 1988 a. The reproductive biology of the cape mole-rat, Georychus capensis (Rodentia, Bathyergidae). Journal Zoological of London, 214, 95-106.

Bennett N.C. \& Jarvis J.U.M. 1988 b. The social structure and reproductive biology of colonies of the mole-rat, Cryptomys damarensis (Rodentia, Bathyergidae). Journal of Mammalogy, 69 (2), 293-302.

Bodmer, R.; Lozano; E.P.; Fang, T.G. 2004. Economic analyses of wildlife uses in the Peruvian Amazon. In: Silvins, K.M.; Bodmer, R. E; Fragoso, J.M.V. (Eds). People and Nature: Wildlife Conservation in South and Central America. Columbia University Press, EUA. pp. 191- 207.

Bonaudo, T.; Le Pendu, Y.; Faure, J.F.; Quanz, D. 2005. The effects of deforestation on wildlife along the transamazon highway. European Journal of Wildlife Research, 51, 199-206.

Faulkes, C.G.; Abbott, D.H.; Jarvis, J.U.M. 1990. Social suppression of ovarian cyclicity in captive and wild colonies of naked molerats, Heterocephalus glaber. Journal of Reproduction and Fertility, 88, 559-568.

Ferreira, A.C.S.; Guimarães, D.A.A.; Luz-Ramos, R.S.; Souza, P.C.; Batista, C.R; Ohashi, O.M. 2004. Reproductive developmental phases of male agouti (Dasyprocta sp.) raised in captivity determined by quantitative analysis of spermatogenic cells. Revista Brasileira de Reprodução Animal, 28, 4, 196-201.

Guimarães D.A. 1993. Algumas características reprodutivas da cutia fêmea Dasyprocta prymnolopha (Wagler, 1831) criada em cativeiro. Dissertação de Mestrado, Universidade Federal do Pará, Belém, Pará. $89 \mathrm{p}$.

Guimarães, D.A. 2000. Aspectos reprodutivos e endócrinos da puberdade, ciclo estral, gestação e cio pós-parto de cutias (Rodentia: Dasyproctidae), criadas em cativeiro. Tese de Doutorado, Universidade Federal do Pará, Belém, Pará. 94p.
Guimarães, D.A.A.; Moreira, D.; Vale, W.G. 1997. Determinação do ciclo reprodutivo da cutia (Dasyprocta prymnolopha) através do diagnóstico colpocitológico. Acta Amazônica, 27(1): 55-64.

Hafez, E.S.E. 2004. Reprodução Animal, 7a Ed., Manole: São Paulo, Brasil. p. 582.

Hensworth, P.H. 1999. Managing the social and sexual environment of the breeding herd to optimize pig reproduction. XI Congresso Brasileiro de Veterinários Especialistas em Suinos. Belo Horizonte, Brasil. p.13-19.

Roth-Kolar H. 1957. Beitrage zum einem aktionssystem des aguti. Zeitschrift Tierpsychologie, 14: 362-375.

Smith N.J. 1976. Utilization of game along Brazil's transamazon highway. Acta Amazonica, 6 (4), 455-466.

Stockard C.R. \& Papanicolau G.N. 1919. The vaginal closure membrane, copulation, and the vaginal plug in the guinea-pig, with further considerations of the oestrous rhythm. Biological Bulletin, 37, 222-245.

Van Aarde R.J. \& Van Wyk V. 1991. Reproductive inhibition in the cape porcupine Hystrix africaeaustralis. Journal of Reproduction and Fertility, 92, 13-19.

Weir B.J. 1971. Some observations on reproduction in the female agouti, Dasyprocta agouti. Journal of Reproduction and Fertility, 24, 203-211.

Weir B.J. 1974. Reproductive characteristics of hystricomorph rodents. Symposium of Zoological Society of London, 34, 265301 .

Wetterberg G.B.; Ferreira M.; Brito W.L.; de Araújo V.C. 1976. Espécies da fauna amazônica potencialmente preferidas para consumo nos restaurantes de Manaus. Brasil Florestal, 7 (25), 59-68.

Recebido em 05/04/2009

Aceito em 01/09/2009 